\title{
EXPLORING SELF REGULATED ONLINE LEARNING SKILLS OF EFL LEARNERS IN DISTANCE EDUCATION
}

\author{
Dr. Emine KULUSAKLI \\ ORCID: 0000-0001-6240-8050 \\ School of Foreign Languages \\ Malatya Turgut Ozal University \\ Malatya, TURKEY
}

Received: 01/01/2021 Accepted: 13/04/2021

\begin{abstract}
The aim of the current study is to investigate self-regulated learning skills of EFL learners in online English course in distance education. It also aims to explore the relationship between the learners' self-regulated learning skills, their age and gender. With this aim, the Self-Regulated Online Learning Questionnaire (SOL-Q) was conducted in order to assess learners' self regulated online learning skills in terms of five sub dimensions including metacognitive skills, time management, environmental structuring, persistence and help seeking. 120 students studying in various departments of a state university participated in the study. Results revealed that the students could manage their environmental structuring skills at 'good' level. However, they rated themselves moderately successful in metacognitive skills, persistence, help seeking and time management dimensions. Furthermore, the study indicated that there was not a statistically significant difference between female and male EFL learners and no statistically significant difference was found between the learners' age and their self-regulated skills. The study suggested that distance education students need to improve their self-regulated online learning skills in order to be more autonomous learners in learning a foreign language.
\end{abstract}

Keywords: Self-regulated learning, distance education, English, foreign language learning.

\section{INTRODUCTION}

2020 brought important changes in people's life as well as in education life. The pandemic (coronavirus, COVID-19) "made universities across the world mobilise and move all teaching online" (Vilkova \& Shcheglova, 2020, p. 1) so that distance education gained importance all over the world. The students had to take responsibility of their own learning as they had to follow their courses from a distance far from the physical classroom environment. They should also "actively plan their work, set goals, and monitor their comprehension and the time they spend on learning. These activities can together be defined as selfregulated learning" (Jansen, Van Leeuwen, Janssen, Kester \& Kalz, 2017, p. 7). That means that self regulated learning became necessary for the students if they want to be successful in learning. As a result of this, selfregulation has been paid attention in second language acquisition recently. Previous studies have indicated that self-regulation was context-specific. In other words, self-regulation in the context of online foreign language education needed to be measured separately and accordingly as there were differences between online language learning and traditional in-class learning (Wang \& Zhan, 2020). Similarly, it is assumed that "language learning from a distance has unique challenges. It has always been more problematic than acquiring knowledge in other subjects due to the lack of opportunity for interaction" (Hurd, 2006 cited in Andrade \& Bunker, 2009, p. 47). Keeping this information in mind, the present study aimed to investigate the learners' self-regulated learning habits in the context of online distance education. 


\section{LITERATURE REVIEW}

The concept of self-regulation originated from educational psychology (Wang \& Zhan, 2020). It is defined as "the control that students have over their cognition, behaviour, emotions and motivation through the use of personal strategies to achieve the goals they have established" (Panadero \& Tapia, 2014, pp. 450-451). Various theories appeared to explain the flow of self-regulated learning in the literature such as the models by Zimmerman (2001), Boekaerts (1999) and Winne (1996). While social cognitve theory constitutes a base for Zimmerman's model, Boekaerts' model (1999) is "more situated, exploring the influence of the context in the type of goals the students pursue" and "Winnie's model is highly cognitive" (Panadero \& Tapia, 2014, p. 450). Zimmerman's model contains processes based on other self- regulation theories (Panadero \& Tapia, 2014). Zimmerman's (2000) model displays self-regulated learning process with the management of three phases such as performance, self-reflection and forethought. To be more specific, performance phase is comprised of self-control (imagery, self-consequences, time management, task strategies, self-instruction, environmental structuring, help seeking, interest enhancement) and self-observation (metacognitive, monitoring, self-recording). Self-reflection phase includes self-reaction (adaptive/defensive, self-satisfaction/ affect) and self-judgement (self-evaluation, casual attribution). Forethought phase is consisted of task analysis (goal-setting, strategic planning) and self-motivation beliefs (goal orientation, self-efficacy, task interest/value, outcome expectations) (cited in Panadero, 2017, p. 5). Learners who are self-regulated in their learning seem to accomplish more positive academic outcomes than those who don't show self-regulated learning behaviors. Self-regulated learning is related with volitional and active behaviors which contain task strategies, time management, environment structuring, goal setting, help-seeking (Barnard-Brak, Paton \& Lan, 2010) and metacognitive skills.

Metacognition is "... thinking about thinking. Learners who are metacognitively aware know what to do when they don't know what to do; that is, they have strategies for finding out or figuring out what they need to do" (Anderson, 2002, p. 2) or "one's knowledge concerning one's own cognitive processes and outcomes or anything related to them" (Flavell, 1976, p. 906 cited in Feiz, 2016, p. 460). It is also "a complex of phenomena related to knowledge about the domain of cognition - consisting of all the mental activities connected with thinking, knowing, and remembering - and its regulation" (Oz, 2005, p. 147). It was recommended that programmes promoting teacher training and language teachers needed to spend time to metacognitive training so as to better comprehend learners and lead to autonomous and self-directed students (Oz, 2005). Likewise, according to Ambreen, Haqdad and Saleem (2016), affective, metacognitive, cognitive and motivational strategies namely learning strategies constituted self-regulated learning and using higher thinking of metacognitive strategies in writing and reading promoted self-regulation of the students. The study also indicated that distance education learners reported that they had high degree of self-regulated learning skills and metacognition and self-evaluation were among vital predictors of academic achievement at tertiary level. It was suggested that the teachers could support and guide learners to improve their executive control strategies.

Adiguzel and Orhan (2017) explored whether self-regulation and metacognitive skills influenced preparatory class students' academic achievements in learning English. The study indicated that the participants had high levels of metacognitive and self regulation skills. Furthermore, the female participants had higher levels of self-regulation and metacognitive skills than males, however; no significant difference was found in the participants' faculties, age, type of graduation and education and these skills.

Feiz (2016) examined the influence of metacognitive awareness on prospective English teachers' attitudes towards English learning. The research displayed that there was a significant difference between the learners' attitudes toward learning a foreign language and their perceived metacognitive awareness. The result also suggested that taking conscious steps to comprehend what was learned and metacognitive awareness could lead to learn a foreign language successfully.

Time management is another part of self-regulated learning. It was consisted of the time and the duration of time for studying or doing an activity. It was also an important skill for learners studying at a distance education because such responsibilities as family and work and distractions affected working on a distance course (Andrade \& Bunker, 2009). Ozturk and Cakiroglu (2018) investigated the correlation between university students' academic achievements and their self-regulated learning skills in Flipped EFL course. 
The findings of the study showed a strong relationship between self-evaluation and task strategies and academic achievement. Moreover, a moderate correlation was found between environment structuring, goal setting and academic achievement. The modest correlation was found in help seeking, time management and academic achievement.

Another feature of self-regulation is environmetal structuring. Bandura (1986) considers human functioning as "a series of reciprocal interactions between behavioral, environmental, and personal variables" (cited in Schunk \& Zimmerman, 1997, p. 196) in the social cognitive theory. For instance, the effect of environment on behaviour appears "when teachers introduce an unusual stimulus or novel event (environmental variable) and students direct their attention toward it (behavior)" (Schunk \& Zimmerman, 1997, p. 196). The learners studying in distance education don't study in a controlled and structured classroom so that "they must be able to structure their own physical learning environment, whether at home or elsewhere" (Lynch $\&$ Dembo, 2004, p. 4 cited in Kirmizi, 2013, p. 163).

Help seeking is necessary for accomplishing a self-regulated learning for language learners and defined as "an achievement behavior involving the search for and employment of a strategy to obtain success" (Ames \& Lau, 1982, p. 414) and is also a vital metacognitive and self-regulatory skill (cited in Koc \& liu, 2016, p. 27). Help seeking is an important learning strategy as it can imply that learners do not have the capacity of satisfactory performance or completing a task without help and this may threaten self-worth. University students hesitate to seek help in that it is "an admission of defeat, embarrassing, and something to be avoided whenever possible" (Karabenick \& Dembo, 2011, p. 33). In the study, Koc and Liu (2016) sought for graduate students' experiences, attitudes and help-seeking preferences in online courses. The study revealed that most of online learners utilized self-regulatory strategies in their help-seeking process.

Persistence is also an important part of self-regulation. It is assumed that persistence in completing an activity needs self-regulation when a task becomes difficult, boring or needs mental or physical effort (Hennecke, Czikmantori \& Brandstätter, 2018).

Studies have shown that self-regulation of the students in online education is prominent for effective language learning. Ekici, Coskun and Yurdugul (2014) studied on the link between online self regulation and learning. The participants of the study were comprised of 303 university students who attended online distance courses of a public university in Turkey. The findings indicated that learning approaches had an important influence on online self-regulation behaviour. Additionally, self-regulation was found to be a prominent effect in online learning owing to learner autonomy. Su, Zheng, Liang and Tsai (2018) aimed to seek for the correlation between self-efficacy and online self-regulation of EFL learners who studied English at a university in China. The result of the study demonstrated that some factors of self-regulation including goal setting, environment structuring and self evaluation dimension positively affected the participants' self-efficacy. Specifically, the participants revealed the strongest agreement on the factor of environment structuring followed by goal setting, help seeking, self-evaluation, time management and task strategies. Albelbisi and Yusop (2019) acknowledged that the learners who had a high level of selfregulated learning were those who were successful in a Massive Open Online Course (MOOC) environment. Students' positive attitude towards MOOC could also help them develop their self-regulated skills and affect their achievement in learning.

In the light of the information given above, the current study aimed to understand EFL learners' self regulated online learning in English course and to explore whether their self regulation differed according to gender and age variables. With this aim, the following research questions were asked so as to find proper responses:

1. What are EFL learners' self regulated skills in online English course?

2. Is there a significant difference between EFL learners' self-regulated online learning and their age in online English course?

3. Is there a significant difference between EFL learners' self-regulated online learning and their gender in online English course? 


\section{METHOD}

So as to give responses to the research questions above, the present study was designed as a descriptive type of general survey research design with a quantitative method. The participants were informed that their participation in the study was completely voluntary and would not affect their grade in the course. The data were collected through online survey in 2020/2021 academic year. The data collected from the participants were firstly coded and then analyzed through SPSS 20. Specifically, descriptive statistics such as means and standard deviations were computed so as to show the learners' responses to self-regulated online learning items. Additionally, t-test and one-way ANOVA tests were conducted in order to find out the differences between self-regulated online learning skills of the students and their gender and age.

\section{Participants}

The current study consisted of 120 students studying in various faculties and a vocational school of a public university located in the Eastern Turkey. They were all first grade students and taking online English course for a year. Approximately $66.7 \%$ of the students identified themselves as female $(n=80)$ while $33.3 \%$ identified themselves as male $(n=40)$. With values for age ranging from 18 to 44 years old, the mean age of participants was 20 with a standard deviation of 2.98. There were $69(57.5 \%)$ participants between the ages of $18-19,37(30.8 \%)$ participants between the ages of 20-21, 9 (7.5) participants between the ages of $22-23$, and $5(4 \%)$ participants aged 24 and above.

\section{Data Collection and Analysis}

Owing to the corona virus pandemic, it was decided to implement the survey online. For this purpose, the participants were sent an invitation by email to fill out SOL-Q. The invitation was sent in week 10 of the English course to make sure participants could reflect on their actual self-regulation behaviours and it was opened to the students for two weeks. The study focused on gender and age as these variables can contribute to self-regulation in learning a foreign language. The independent variables were students' age and gender while self-regulated online learning scale points constituted the dependent variable. Quantitative data analysis was followed so as to analyze the data collected from the students. The data were analyzed through an IBM SPSS Statistics 20 program. An independent Samples T-Test was implemented to compare the mean scores obtained from the SOL-Q in terms of gender and self-regulated online learning and a One-Way ANOVA test was conducted if there was a statistically significant difference depending on the participants' age.

\section{The Self-Regulated Online Learning Questionnaire (SOL-Q)}

The data was collected through the Self-Regulated Online Learning Questionnaire (SOL-Q). The SOL-Q originally developed by Jansen, Van Leeuwen, Janssen, Kester, and Kalz (2017) was used to measure the students' self-regulation behaviours in the online learning process. The questionnaire was adapted into Turkish by Yavuzalp and Ozdemir (2020) and utilized for the purpose of the research. The scale was comprised of 36-item scale with a 7-point Likert-type response format ranging from "not at all true for me" (=1) to "very true for me" (=7). The findings were commented as 'excellence level' (=.71), 'very good' level (=.63), 'good' level (=.55), 'moderate' level (=.45) and 'poor' level (.32) (Yavuzalp \& Ozdemir, 2020). The scale had five sub dimensions as metacognitive skills, help seeking, time management, persistence and environmental structuring. Specifically, it was consisted of metacognitive skills with 18 items, time management with 3 items, environmental structuring with 5 items, persistence with 5 items and help seeking with 5 items. The overall Cronbach's alpha value was found to be .93 for the present study. 


\section{RESULTS}

\section{EFL learners' Self Regulated Online Learning Skills}

In order to give a response to the first research question which was asked to elicit distance education learners' self-regulated online learning habits, the descriptive statistics as mean scores and standard deviations were given in tables below. Table 1 showed the distance education learners' responses about their meatcognitive skills.

Table 1. Descriptive results of the students' metacognitive skills in online English course

\begin{tabular}{lcc}
\hline Metacognitive skills & M & SD \\
\hline 1.I think about what I really need to learn before I begin a task in this online course. & 5.06 & 1.49 \\
2. I ask myself questions about what I am to study before I begin to learn for this online course. & 4.13 & 1.50 \\
3.I set short-term (daily or weekly) goals as well as long-term goals (monthly or for the whole online & 4.65 & 1.59 \\
course). & 4.96 & 1.41 \\
4.I set goals to help me manage my studying time for this online course. & 4.73 & 1.63 \\
5.I set specific goals before I begin a task in this online course. & 5.41 & 1.41 \\
6.I think of alternative ways to solve a problem and choose the best one for this online course & 5.71 & 1.26 \\
7.I try to use strategies in this online course that have worked in the past. & 4.88 & 1.32 \\
8.I have a specific purpose for each strategy I use in this online course. & 5.55 & 1.23 \\
9.I am aware of what strategies I use when I study for this online course. & 5.38 & 1.51 \\
10. Although we don't have to attend daily classes, I still try to distribute my studying time for this & \\
online course evenly across days. & 4.76 \\
11.I periodically review to help me understand important relationships in this online course. & 1.38 \\
12.I find myself pausing regularly to check my comprehension of this online course. & 4.61 & 1.56 \\
13. I ask myself questions about how well I am doing while learning something in this online course. & 5.05 & 1.48 \\
14.I think about what I have learned after I finish working on this online course. & 5.27 & 1.32 \\
15. I ask myself how well I accomplished my goals once I'm finished working on this online course. & 4.78 \\
16.I change strategies when I do not make progress while learning for this online course. & 5.25 & 1.48 \\
17.I find myself analyzing the usefulness of strategies while I study for this online course. & 4.90 & 1.39 \\
18. I ask myself if there were other ways to do things after I finish learning for this online. & 4.93 & 1.50 \\
\hline Total mean & 5.00 & 1.01 \\
\hline
\end{tabular}

As shown in Table 1, the total mean of the metacognitive skills was 5.00 and it was at "good" level. The students reported that they tried to use strategies in online English course that had worked in the past $(M=5.71)$ at "very good" level. They were aware of what strategies they used when they studied for online English course $(M=5.55)$ at "good" level. They reported that they asked themselves questions about what they were to study before they began to learn for online English course $(\mathrm{M}=4.13)$ at "very poor" level. The students reported that they were at "moderate" level for the rest of the items in the subscale of metacognitive skills. 
Table 2. Descriptive results of the students' time management in online English course

\begin{tabular}{lcc}
\hline Time management & M & SD \\
\hline 19.I find it hard to stick to a study schedule for this online course. & 4.25 & 1.79 \\
20. I make sure I keep up with the weekly readings and assignments for this online course. & 5.61 & 1.28 \\
$\begin{array}{l}\text { 21. I often find that I don't spend very much time on this online course because of other } \\
\text { activities. }\end{array}$ & 4.10 & 2.03 \\
\hline Total mean & 4.65 & 1.19 \\
\hline
\end{tabular}

The total mean score of time management was 4.65 and it was at 'moderate' level as indicated in Table 2. In more details, the students made sure they kept up with the weekly readings and assignments for online English course at 'good' level. However, they found it hard to stick to a study schedule for online English course $(M=4.25)$ and they often found that they didn't spend very much time on online English course because of other activities $(\mathrm{M}=4.10)$ at 'poor' level.

Table 3. Descriptive results of the students' environmental structuring in online English course

\begin{tabular}{lcc}
\hline Environmental structuring & M & SD \\
\hline 22. I choose the location where I study for this online course to avoid too much distraction. & 5.88 & 1.40 \\
23. I find a comfortable place to study for this online course. & 6.18 & 1.16 \\
24. I know where I can study most efficiently for this online course. & 5.92 & 1.43 \\
25. I have a regular place set aside for studying for this online course. & 5.89 & 1.35 \\
26. I know what the instructor expects me to learn in this online course. & 5.78 & 1.25 \\
\hline Total mean & 5.93 & 1.00 \\
\hline
\end{tabular}

As Table 3 demonstrated that the total mean score for environmental structuring was 5.93 and it was at 'good' level. The students reported that they found a comfortable place to study (M=6.18), they knew where they could study most efficiently $(M=5.92)$, they had a regular place set aside for studying $(M=5.89)$, they chose the location where they studied to avoid too much distraction $(\mathrm{M}=5.88)$ and they knew what the instructor expected them to learn in English online course $(M=5.78)$ at 'good level'.

Table 4. Descriptive results of the students' persistence in online English course

\begin{tabular}{lcc}
\hline Persistence & M & SD \\
\hline 27. When I am feeling bored studying for this online course, I force myself to pay attention. & 5.42 & 1.50 \\
28. When my mind begins to wander during a learning session for this online course, I make a & 5.57 & 1.42 \\
special effort to keep concentrating. & 5.35 & 1.53 \\
29. When I begin to lose interest for this online course, I push myself even further. & 5.46 & 1.43 \\
30. I work hard to do well in this online course even if I don't like what I have to do. & 5.20 & 1.53 \\
31. Even when materials in this online course are dull and uninteresting, I manage to keep & & \\
working until I finish. & 5.40 & 1.16 \\
\hline Total mean & & \\
\hline
\end{tabular}

The total mean score for persistence was 5.40 and it was at 'moderate' level as revealed in Table 4 . The students stated that when their mind begins to wander during a learning session for online English course, they made a special effort to keep concentrating $(M=5.57)$ at 'good' level. They worked hard to do well in online English course even if they didn't like what they had to do $(M=5.46)$, when they were feeling bored studying, they forced themselves to pay attention $(M=5.42)$, when they began to lose interest for online English course, they pushed themselves even further $(M=5.35)$ and even when materials in online English course are dull and uninteresting, they managed to keep working until they finished $(\mathrm{M}=5.20)$ at 'moderate' level. 
Table 5. Descriptive results of the students' help seeking in online English course

\begin{tabular}{lcc}
\hline Help seeking & M & SD \\
\hline $\begin{array}{l}\text { 32. When I do not fully understand something, I ask other course members in this online } \\
\text { course for ideas. }\end{array}$ & 4.83 & 1.73 \\
$\begin{array}{l}\text { 33. I share my problems with my classmates in this online course so we know what we are } \\
\text { struggling with and how to solve our problems. }\end{array}$ & 5.22 & 1.72 \\
34. I am persistent in getting help from the instructor of this online course. & 4.03 & 1.62 \\
35. When I am not sure about some material in this online course, I check with other people. & 5.31 & 1.65 \\
36. I communicate with my classmates to find out how I am doing in this online course. & 4.35 & 2.02 \\
\hline Total mean & 4.75 & 1.29 \\
\hline
\end{tabular}

As displayed in Table 5, the total mean score for help seeking was 4.75 and it was at 'moderate' level. The students reported that when they were not sure about some material in online English course, they checked with other people $(M=5.31)$, they shared their problems with their classmates in online English course so they knew what they were struggling with and how to solve their problems $(M=5.22)$ and when they did not fully understand something, they asked other course members in online English course for ideas $(M=4.83)$ at 'moderate' level. They I communicated with their classmates to find out how they were doing in online English course $(\mathrm{M}=4.35)$ and they were persistent in getting help from the instructor of online English course $(\mathrm{M}=4.03)$ at 'poor' level.

\section{EFL Learners' Self Regulated Online Learning Skills and Gender}

The second research question was asked so as to understand whether gender affected the learners' self regulated online learning skills and the results were given in Table 6 below.

Table 6. Results on students' self-regulated online English learning in terms of gender

\begin{tabular}{|c|c|c|c|c|c|c|}
\hline Group & Gender & $\mathrm{N}$ & M & Sd & $\mathrm{t}$ & $\mathrm{p}$ \\
\hline \multirow[t]{2}{*}{ Metacognitive skills } & Female & 80 & 4.94 & 1.00 & -.889 & .37 \\
\hline & Male & 40 & 5.11 & 1.00 & -.890 & \\
\hline \multirow[t]{2}{*}{ Time management } & Female & 80 & 4.67 & 1.19 & .289 & .77 \\
\hline & Male & 40 & 4.60 & 1.18 & .290 & \\
\hline \multirow[t]{2}{*}{ Environmental structuring } & Female & 80 & 5.97 & 1.01 & .963 & .33 \\
\hline & Male & 40 & 5.78 & 1.03 & .957 & \\
\hline \multirow[t]{2}{*}{ Persistence } & Female & 80 & 5.44 & 1.20 & .849 & .39 \\
\hline & Male & 40 & 5.25 & 1.09 & .878 & \\
\hline \multirow[t]{2}{*}{ Help seeking } & Female & 80 & 4.84 & 1.24 & 1.117 & .26 \\
\hline & Male & 40 & 4.56 & 1.35 & 1.087 & \\
\hline
\end{tabular}

As could be seen in Table 6 , gender was not a statistically significant contributor to the students perceptions of self regulated online learning for all of the subscales namely metacognitive skills, time management, environmental structuring, persistence and help seeking. The mean score of the female participants $(X=$ 4.94) was lower than the mean score of their male counterparts $(X=5.12)$ only in the factor of metacognitive skills. Nevertheless, the mean scores of the female participants were higher than the mean scores of the male participants in the factors of time management $(X=4.66)$, environmental structuring $(X=5.99)$, persistence $(X=5.46)$ and help seeking $(X=4.84)$. The results displayed that the students' gender did not influence their self regulated online learning perceptions in learning English. 


\section{EFL Learners' Self Regulated Online Learning and Age}

The third research question was designed in order to elicit whether there was a difference between learners' self-regulated online learning and their age and Table 7 demonstrated the results below.

Table 7. Results on students' self-regulated online English learning in terms of age

\begin{tabular}{|c|c|c|c|c|c|c|}
\hline & Age & $\begin{array}{l}\text { Sum of } \\
\text { Squares }\end{array}$ & df & $\begin{array}{l}\text { Mean } \\
\text { Square }\end{array}$ & $\mathrm{F}$ & Sig. \\
\hline \multirow[t]{3}{*}{ Metacognitive skills } & Between groups & .797 & 1 & .797 & .790 & .376 \\
\hline & Within groups & 119.029 & 118 & 1.009 & & \\
\hline & Total & 119.826 & 119 & & & \\
\hline \multirow[t]{3}{*}{ Time management } & Between groups & .119 & 1 & .119 & .083 & .773 \\
\hline & Within groups & 167.525 & 118 & 1.420 & & \\
\hline & Total & 167.644 & 119 & & & \\
\hline \multirow{4}{*}{$\begin{array}{l}\text { Environmental } \\
\text { structuring }\end{array}$} & Between groups & .963 & 1 & .963 & .928 & .337 \\
\hline & & 122.461 & 118 & 1.038 & & \\
\hline & Within groups & 123.424 & 119 & & & \\
\hline & Total & & & & & \\
\hline \multirow[t]{3}{*}{ Persistence } & Between groups & .988 & 1 & .988 & .720 & .398 \\
\hline & Within groups & 161.938 & 118 & 1.372 & & \\
\hline & Total & 162.927 & 119 & & & \\
\hline \multirow[t]{3}{*}{ Help seeking } & Between groups & 2.053 & 1 & 2.053 & 1.248 & .266 \\
\hline & Within groups & 194.127 & 118 & 1.645 & & \\
\hline & Total & 196.180 & 119 & & & \\
\hline
\end{tabular}

As indicated in Table 7, there was not a statistically significant difference between the learners' age and self regulated online learning namely metacognitive skills, $\mathrm{F}(1,118)=.790, \mathrm{p}>0.05$, time management, $\mathrm{F}(1,118)=.083, \mathrm{p}>0.05$, environmental structuring, $\mathrm{F}(1,118)=.928, \mathrm{p}>0.05$, persistence, $\mathrm{F}(1,118)=.720$, $p>0.05$ and help seeking $F(1,118)=1.248, p>0.05$. In other words, the participants' age did not contribute to their perceptions of self-regulated online learning.

\section{DISCUSSIONS AND CONCLUSION}

This study employed the Self-Regulated Online Learning questionnaire to explore the perceptions of EFL learners' online self-regulation in online English course and to investigate whether there was a difference between their self-regulated skills and age along with gender. The study examined EFL learners' self-regulated learning in online English course in the subscales of metacognitive skills, time management, environmental structuring, persistence and help seeking.

Firstly, this study found that distance education learners obtained the highest mean score in the factor of environmental structuring. That meant that they rated themselves good enough in environmental structuring as they had the ability to find a comfortable place to study and to know the place to study most effectively. This finding was in accordance with previous findings which showed that "in order to achieve more effective online learning, learners usually need to use these strategies to restructure their learning settings for high concentration" (Boekaerts et al., 2005; Zimmerman \& Risemberg, 1997 cited in Su, Zheng \& Tsai 2018, p. 114). Distance education learners must have the capacity to form a suitable physical environment wherever they studied (Lynch \& Dembo cited in Kirmizi, 2013). 
Secondly, distance education learners found themselves moderately successful in metacognitive skills. Specifically, in terms of metacognitive skills, they attempted to utilize learning strategies they used before most efficiently to be successful in online English course and they were conscious enough to choose the suitable strategies while studying English. On the other hand, they failed to ask questions about what to study before studying online English course since they rated themselves at poor level. In order to make students successful in metacognitive skills, it was recommended that necessary steps should be taken (Feiz, 2016) and teacher training programmes should include metacognitive training to comprehend their students and make the students autonomous $(\mathrm{Oz}, 2005)$.

Thirdly, in accordance with time management, distance education learners could manage their time at moderate level. However, they could not manage their time efficiently in online English course due to other activities and they had difficulties with following a study programme in online English course.

Fourthly, distance education learners obtained the second highest mean scores in the subscale of persistence after environmental structuring as they rated themselves moderately successful in this part. Specifically speaking, they put extra effort to concentrate on a learning session for online English course even if their mind started wandering or they lost interest or got bored.

Finally, in terms of help seeking, distance education learners found themselves moderately successful. Specifically, they shared their problems with other people in the class and sought help from them when they want to learn about some material in the course moderately. Although they were willing to seek help when studying online English course, they had difficulties in communicating with their classmates about their progress in online English course. Interestingly, it was found out that distance education learners reported that they hesitated to seek help from their teachers of online English course since they got the lowest mean score in this item. This was because students studying at tertiary level had some difficulties with getting help from other people such as their classmates and instructors as they felt embarrassed and avoided seeking help (Karabenick \& Dembo, 2011, p. 33).

In accordance with the second research question of the study, distance education learners' self-regulated habits were examined in relation to age and gender. The results revealed that there were not significant differences between female and male participants. Additionally, there were not statistical differences between self-regulated online learning habits and distance education learners' age.

This study explored to understand distance education learners' self regulated online learning skills in online English course depending on age and gender. The results displayed that distance education learners needed to improve their self regulated learning habits as they must take the responsibility of their own learning so as to be successful in learning. They especially needed to improve their metacognitive skills, manage their time efficiently and persist in following the course effectively. Moreover, they should not avoid seeking help from their peers, teachers or other people when needed. In order to develop their self-regulation in learning a foreign language, distance education learners should be trained. To be more specific, they should have strategy training from their instructor in order to be autonomous learners. To achieve this, the instructors should also know how to train their students so that they also needed to be autonomous.

\section{LIMITATIONS}

This study had several limitations. Firstly, this study was conducted with the participants studying at different departments of a state university in Turkey so that this limits the generalizability of the results. Future studies can be conducted with a large amount of participants. Secondly, the study used self-reports of the learners responded to the Self-regulated Online Learning Questionnaire. However, it is insufficient for analysing the dynamics of self-regulation. Future studies can include qualitative data collecting tools. Thirdly, this study was administered in order to determine distance education learners' self-regulated habits in online English course of a university, however, future research can be conducted in other educational settings. 


\section{BIODATA AND CONTACT ADDRESSES OF AUTHOR}

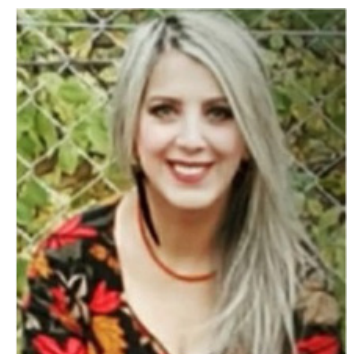

Dr. Emine KULUSAKLI is an assistant professor in the School of Foreign Languages at Malatya Turgut Ozal University. She gained her Ph.D. in English Language and Literature at Istanbul Aydin University. Her academic interest areas are language learning and teaching, distance learning, online learning in higher education and learner autonomy. She is also interested in British literature and American literature. She has more than 8 journal articles published in international indexes, 1 book chapter and more than 15 papers submitted to international meetings.

Emine KULUSAKLI

School of Foreign Languages

Address: Malatya Turgut Ozal University, 4400, Malatya, Turkey

Phone: +90 4228461255

E-mail: emine.kulusakli@ozal.edu.tr

\section{REFERENCES}

Adiguzel, A., \& Orhan, A. (2017). The relation between English learning students' levels of self- regulation and metacognitive skills and their English academic achievements, Journal of Education and Practice, 8(9), 115-125.

Albelbisi, N., \& Yusop, F. (2019). Factors influencing learners' self -regulated learning skills in a massive open online course (MOOC) environment. Turkish Online Journal of Distance Education, 20(3), 1-16. https://doi: 10.17718/tojde.598191.

Ambreen, M, Haqdad, A., \& A. Saleem, W. (2016). Fostering self- regulated learning through distance education: A case study of M.Phil secondary teacher education program of Allama Iqbal open university. Turkish Online Journal of Distance Education, 17 (3), 120-135. https://doi: 10.17718/ tojde.89562.

Ames, R., \& Lau, S. (1982). An attributional analysis of help-seeking in academic settings. Journal of Educational Psychology, 74, 414-423.

Anderson, N. J. (2002). The role of metacognition in second language teaching and learning. ERIC Digest. Washington, DC: Center for Applied Linguistics.

Andrade, M.S., \& Bunker, E. (2009). A model for self-regulated distance language learning, Distance Education Melbourne, 30(1), 47-62.

Bandura, A. (1986). Social foundations of thought and action: A social cognitive theory. Englewood Cliffs, NJ: Prentice Hall.

Barnard-Brak, L., Paton, V., \& Lan, W. (2010). Profiles in self-regulated learning in the online learning environment. International Review of Research in Open and Distributed Learning, 11(1), 61-80. https://doi.org/10.19173/irrodl.v11i1.769.

Boekaerts, M. (1999). Motivated learning: Studying student situation transactional units. European Journal of Psychology of Education, 14(1), 41-55. https://doi: 10.1007/bf03173110.

Boekaerts, M., Pintrich, P. R., \& Zeider, M. (2005). Handbook of self-regulation. San Diego, CA: Academic Press.

Ekici, M., Coskun, H. I., \& Yurdugul, H. (2014). Investigation of the relationship between learning approaches and online self-regulation behavior. Procedia-Social and Behavioral Sciences, 141, 285289. https://doi: 10.1016/j. sbspro.2014.05.050

Feiz, P. J. (2016). Metacognitive awareness and attitudes toward foreign language learning in the EFL context of Turkey. Procedia - Social and Behavioral Sciences, 232, 459-470.

Flavell, J. H. (1976). Metacognitive aspects of problem solving. In L. B. Resnick (Ed.), The nature of intelligence (pp. 231-235). Hillsdale, NJ: Lawrence Erlbaum Associates.

Gafaro, B.C. (2019). Exploring self-regulated language learning with MOOCs. Journal of Interactive Media in Education, 1, 14. http://doi.org/10.5334/jime.527. 
Hennecke, M., Czikmantori, T., \& Brandstätter, V. (2018). Doing despite disliking: Self- regula to ry strategies in everyday aversive activities. European Journal of Personality, 33, 104-128.

Hurd, S. (2006). Towards a better understanding of the dynamic role of the distance language learning: Learner perceptions of personality, motivation, roles, and approaches. Distance Education, 27(3), 303-329.

Jansen, R. S., Van Leeuwen, A., Janssen, J., Kester, L., \& Kalz, M. (2017). Validation of the self-regulated online learning questionnaire. Journal of Computing in Higher Education, 29(1), 6-27.

Karabenick, S. A., \& Dembo, M. H. (2011). Understanding and facilitating self-regulated help seeking. New Directions for Teaching and Learning, 126, 33-43. https://doi:10.1002/tl.442.

Kirmizi, O. (2013). Investigating self-regulated learning habits of distance education students. Tarih Kultur ve Sanat Arastirmalari Dergisi, 2(2), 161-174.

Koc, S., \& Liu, X. (2016). An investigation of graduate students' help-seeking experiences, preferences and attitudes in online learning. Turkish Online Journal of Educational Technology, 15(3), 27-38.

Lynch, R., \& Dembo, M. (2004). The Relationship between self-regulation and online learning in a blended learning context. International Review of Research in Open and Distance Learning, 8(4).

Lynch, R., \& Dembo, M. (2004). The relationship between self-regulation and online learning in a blended learning context. The International Review of Research in Open and Distributed Learning, 5(2), 1-16. https://doi.org/10.19173/irrodl.v5i2.189

$\mathrm{Oz}, \mathrm{H}$. (2005). Metacognition in foreign/second language learning and teaching. Hacettepe University Journal of Education, 29, 147-156.

Ozturk, M., \& Cakiroglu, U. (2018). Relationships between students' self-regulated learning skills and academic achievements in a flipped EFL classroom. Inonu University Journal of the Faculty of Education, 19(2), 21-35. https://doi: 10.17679/inuefd.298059.

Panadero, E., \& Tapia, J.A. (2014). How do students self-regulate? Review of Zimmerman's cyclical model of self-regulated learning. Anales de Psicología, 30(2), 450-462. https://dx.doi.org/10.6018/ analesps.30.2.167221

Panadero, E. (2017) A Review of self-regulated learning: Six models and four directions for research. Frontiers in Psychology, 8, 422. https://doi: 10.3389/fpsyg.2017.00422.

Schunk, D. H., \& Zimmerman, B. J. (1997). Social origins of self-regulatory competence. Educational Psychologist, 32, 195-208.

Su, Y., Zheng, C., Liang, J.C., \& Tsai, C. C. (2018). Examining the relationship between English language learners' online self-regulation and their self-efficacy. Australasian Journal of Educational Technology, 34(3), 105-121.

Vilkova, K., \& Shcheglova, I. (2021). Deconstructing self-regulated learning in MOOCs: In search of help-seeking mechanisms. Education and Information Technologies, 26, 17-33. https://doi. org/10. 1007/s10639-020-10244-x

Wang, W., \& Zhan, J. (2020). The relationship between English language learner characteristics and online self-regulation: A structural equation modeling approach. Sustainability, 12(7), 3009.

Winne, P. H. (1996). A metacognitive view of individual differences in self-regulated learning. Learning and Individual Differences, 8(4), 327-353. http://dx.doi.org/10.1016/S1041-6080(96)90022-9.

Yavuzalp, N., \& Ozdemir, Y. (2020). Oz-duzenlemeli cevrimici ogrenme olcegini Turkce'ye uyarlama calismasi. Yuksekogretim Dergisi, 10(3), 269-278. http://doi: 10.2399/yod.19.512415

Zimmerman, B. J., \& Risemberg, R. (1997). Becoming a self-regulated writer: A social cognitive perspective. Contemporary Educational Psychology, 22(1), 73-101. http://dx.doi.org/10.1006/ceps.1997.0919.

Zimmerman, B. J. (2000). Attaining self-regulation. A social cognitive perspective. In: Boekaerts, M, Pintrich, P and Zeidner, M (eds.), Handbook of Self-Regulation, 13-39. San Diego, CA: Academic Press. https://doi. org/10.1016/B978-012109890-2/50031-7.

Zimmerman, B. J. (2001). Theories of self-regulated learning and academic achievement: An overview and analysis. In B. J. Zimmerman \& D. H. Schunk (Eds.), Self-regulated learning and academic achievement (Second ed., pp. 1-37). New York: Lawrence Erlbaum Associates. 